\title{
Periapical Dental Abscess
}

National Cancer Institute

\section{Source}

National Cancer Institute. Periapical Dental Abscess. NCI Thesaurus. Code C34913.

Localized collection of pus in the tissues that enclose the root of a tooth. 